\title{
STUDY OF REFLECTION OF NEW LOW-REFLECTIVITY QUAY WALL CAISSON
}

\author{
Joaquín M. GARRIDO ${ }^{1}$, Daniel PONCE DE LEÓN ${ }^{1}$, Antonio BERRUGUETE ${ }^{1}$, Silvia \\ MARTÍNEZ ${ }^{2}$, José MANUEL ${ }^{2}$, Lisardo FORT ${ }^{2}$, Diego YAGÜE² ${ }^{2}$ Jose A. GONZÁLEZ- \\ ESCRIVÁ $^{3}$ and Josep R. MEDINA ${ }^{3}$
}

This paper presents a new low-reflectivity quay wall caisson based on the formation of cell circuits. The cell circuit
lengths can be adapted to the specific wave climate conditions at the construction site to obtain the best performance.
Results from physical model tests of conventional and cell circuit caissons are described, as well as the construction
process and steel reinforcement, which turns out to be quite similar to highly reflective conventional caissons. Neural
Network (NN) models are used to describe the nonlinear relationship observed between experimental coefficients of
reflection (CR) and the structural and wave conditions for the new low reflectivity quay wall caisson.

Keywords: perforated breakwaters, wave reflection, neural network, caisson, low-reflectivity, quay wall.

\section{INTRODUCTION}

The construction of caissons for vertical breakwaters and quays on the Spanish coast has increased dramatically over the last decade. The overexploitation of coastal quarries and environmental constraints associated with conventional mound breakwaters has favored the expansion of the Spanish fleet of floating docks for constructing floating caissons. Caisson-type vertical breakwaters have construction and environmental advantages over conventional mound breakwaters as well as some drawbacks, such as wave reflection. Wave reflection on quay walls increases harbor disturbance and reduces operational time in commercial seaports. In an effort to increase operability, the reduction of wave reflectivity on quay walls is a goal for designers and port planners in many coastal areas. Prefabricated floating caissons with squared or circular cells are the basic construction element for quay walls in Spanish commercial ports. Therefore, the study of new typologies of low-reflectivity vertical breakwaters and quay walls is an important topic for further research; the study of reflection performance of such structures is necessary for design. Furthermore, low-reflectivity structures are being adopted because their energy absorption capacity provides greater hydraulic stability, reduces scour problems and prevents impulsive forces (Takahashi and Hosoyamada, 1994).

Existing designs for low-reflectivity caissons include: (1) specific designs based on patents or ideas that turn out to be very costly to put into practice and (2) designs based on cutting windows on conventional caisson cells with diamond wire. The latter is the most common solution to reduce wave reflectivity in Spanish seaports (see Fig. 1).
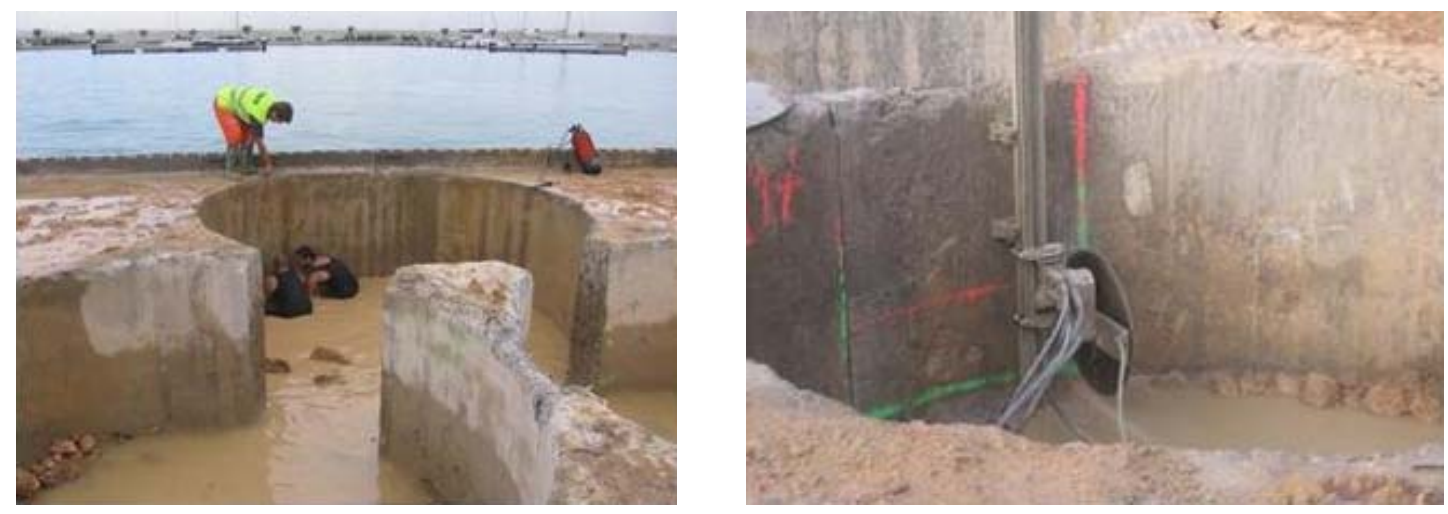

Figure 1.- Construction of wave-dissipating chambers, (a) circular cells and (b) diamond wire cut.

Most low-reflectivity structures are designed after a low-reflectivity structural concept given by Jarlan (1961), which is based on a perforated wall and a wave-energy dissipating chamber.

\footnotetext{
${ }^{1}$ Iberport Consulting S.A., C/Botiguers No 3 Planta 3 Puertas AB, Parque Empresarial Táctica, 46980 Paterna (Valencia), SPAIN

${ }^{2}$ Cyes construction company, C/J.J. Dominé no 6 Pta.5 CP 46011 Valencia, SPAIN

${ }^{3}$ Universidad Politécnica de Valencia, Camino de Vera s/n, 46022 Valencia, SPAIN
} 
First, the wave reaches the front-facing perforated wall; then it is partly reflected and partly transmitted through the perforated wall into the inner chamber. In the chamber, the transmitted wave reflects off of the impermeable back wall and is transmitted through the perforated wall; this wave interferes with the first reflection, attenuating the wave energy. Wave-energy dissipation is also achieved by turbulence within the chamber and flow viscosity passing through wall perforations. In the case of a single chamber, attenuation of wave reflection mainly depends on wave period (T) and distance (B) between the perforated front wall and back wall. The highest energy loss will occur when induced water speed on the perforated wall is maximum; in this case the chamber width is about a quarter of the wavelength (L) inside the chamber $(B=L / 4)$. For low water speed, the energy loss is low and a perforated chamber wall is inefficient $(\mathrm{B}=\mathrm{L} / 2)$. There is an optimum chamber width and perforated wall porosity to achieve the minimum wave reflection.

Jarlan's concept, referred to above, may be used to create multi-chamber low-reflectivity structures. In this case, not one but several perforated walls make the reflection-transmission scheme more complex. In addition, the depths inside and outside of the chambers may be different and the different wall perforations and wave characteristics makes the study of flow behavior for this type of structure very complex.

Additional technical difficulty is introduced if one aims to reduce the wave reflection of the caisson without significantly affecting caisson manufacturing procedures, schedules and costs. A good design requires not only laboratory testing of low-reflectivity structures, but also detailed engineering and specific casting solutions to solve numerous design and construction problems. There are many problems involved with the design process of anchoring a caisson at the construction site that need to be solved: steel concrete reinforcing, prefabrication process, the casting system and navigation, etc. The CADIMA Research Project aims to design a new low-reflective prefabricated floating caisson structure without significantly affecting the construction cost and manufacturing schedule of conventional floating caissons (see Fig. 1). As a result, a low-reflective floating caisson design was found to compete with conventional caissons in terms of both costs and the tight manufacturing schedules.

In this paper, coefficient of reflection (CR) is analyzed for small-scale models of different typologies of the Jarlan-type structures (see Jarlan, 1961) in comparison to new low-reflectivity quay wall caissons using long cell circuits.

\section{A NEW LOW-REFLECTIVITY CAISSON}

\section{Previous studies}

The seminal idea of a low-reflectivity structure was given by Jarlan $(1961,1965)$. Other low-reflectivity designs, similar to the original idea, have been proposed in Japan (Takahashi, 1996), in Italy (Franco, 1994) and Spain (Esteban and Llamas, 2007). Perforated wall caissons are the most widely used solutions for low-reflectivity vertical structures. Typically, perforated walls may have vertical or horizontal slots as well as circular or rectangular holes. Wall porosity is defined as the relation between the perforated area and total area of the wall; wall porosity is usually between $15 \%$ and $40 \%$ and the width of the chamber (B) is between $1 / 10$ and $1 / 4$ of the local wave length in the basin. Despite the variety of typologies and the growing use of lowreflective structures, knowledge about complex hydraulic behavior and hydrodynamic forces is very limited.

Jarlan (1961) tested at 1/30 scale, a caisson with a perforated front wall with holes and a porosity of $49 \%$. He concluded that the reduction of wave reflection was significant for certain values of wavelength. Marks and Jarlan (1968) included tests with irregular waves to study the forces on perforated structures. Jianyi (1992) tested a drilled type vertical caisson breakwater with advantages of low CR and decreased wave agitation. Bergmann et al. (2000) compared results of wave reflection in single and multiple chamber caisson docks and found a reduction in force on the structure for a wider range of frequencies than a single chamber. Dhinakaran et al. (2002) carried out physical tests to study the hydraulic behavior and the pressures of a typology consisting of a mixed semicircular caisson over a rubble mound bedding-layer with small horizontal forces compared with the vertical breakwater. Tabet-Aoul and Lambert (2003) conducted tests within the European PROVERBS research project and proposed an empirical 
method to calculate maximum horizontal forces from the results of those tests and additional data from prototype observations. Recent physical experiments on Jarlan-type breakwaters were carried out by Garrido and Medina (2006, 2007) and Martinez et al.(2010). Relative chamber width, being optimal at $\mathrm{B} / \mathrm{L}=0.2$, was the most critical parameter. For low-reflectivity Jarlantype breakwaters, the relative chamber width is most effective when $0.1<\mathrm{B} / \mathrm{L}<0.3$ for singlechamber, and $\mathrm{B} / \mathrm{L}>0.1$ for double-chamber schemes, with porosities lower than $50 \%$. For lowreflectivity Jarlan-type breakwaters, the relative chamber width is the most effective solution when it is $0.1<\mathrm{B} / \mathrm{L}<0.3$ for single-chamber and $\mathrm{B} / \mathrm{L}>0.1$ for double-chamber schemes, both cases with porosities lower than $50 \%$.

A variety of theoretical models have also been developed. Jarlan (1965), Kondo (1979), Hagiwara (1984), Fugazza and Natale (1992), Suh and Park (1995), Takahashi et al. (2002), Kakuno at al. (2003), have conducted studies for the calculation of CR on low-reflectivity vertical breakwaters.

At the conclusion of all of these studies it was found that the effectiveness of lowreflectivity structures, related to the dimensionless parameter $\mathrm{B} / \mathrm{L}$, is conditioned by construction restrictions and execution costs, because it is usually not possible to achieve the desired chamber width (B) necessary to reduce the CR.

\section{New low-reflectivity design}

The new concept of a multi-cell circuit scheme has been proposed as especially effective in reducing wave reflection of low-frequency waves (Medina et al., 2009).

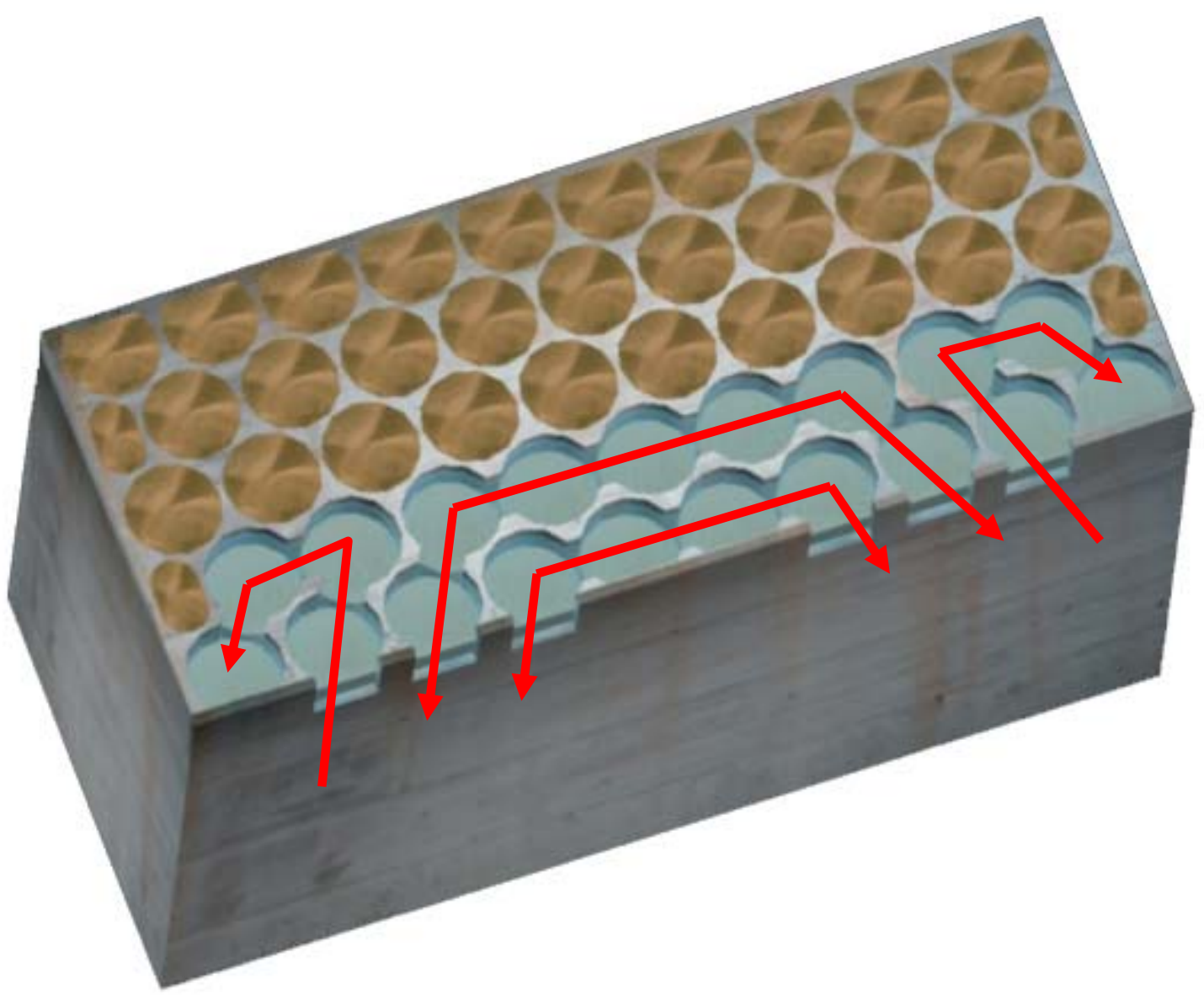

Figure 2.- New low-reflectivity caisson type.

The basic idea of the multi-cell circuit scheme (Fig. 2) is to connect caisson cells in two different directions to form cell circuits with the adequate length to attenuate the incident waves at the construction site. The cell circuits may be long enough to efficiently attenuate long waves and to optimize caisson performance under low-frequency incident waves. Instead of caisson 
performance being conditioned by the width of the anti-reflective zone, which is fixed in most cases, a caisson can be designed to be especially efficient in reducing wave reflection of a given spectral bandwidth, including very low-frequency waves. As an extreme case, the multi-cell circuit scheme can be used to form multiple chambers, as long as Lc $>100$ meters, to attenuate very low-frequency waves which may cause resonance problems in the inner part of a harbor. For the most common application, the multi-cell circuit scheme may be adapted to obtain a caisson especially efficient in reducing wave-reflection for a specific frequency band. Therefore, instead of one design-fits-all strategy of many low-reflective structures, the multicell circuits concept can be adapted to obtain the maximum efficiency in wave reflection reduction for specific caissons in a given harbor zone. It is necessary to take into consideration that incident waves on the caissons, the reflection of which must be attenuated, have different frequencies in different harbor areas.

In order to verify the effectiveness and feasibility of this new low-reflectivity caisson, wave frequencies were classified in three categories: very high $(\mathrm{f}[\mathrm{Hz}]>0.2)$, high $(0.2<\mathrm{f}[\mathrm{Hz}]<0.1)$ and low $(\mathrm{f}[\mathrm{Hz}]<0.1)$. Constructive constraints were taken into consideration for the manufacturing system of floating docks and pontoons, modifications of formwork sliding procedures, steel concrete reinforcement, flotation properties, towing process and navigability, anchoring procedure and superstructure execution. Both equipment and manufacturing procedures must be adapted to produce these economically-efficient low-reflectivity caissons.

\section{PHYSICAL MODEL TESTS}

Small-scale physical experiments were conducted in the wave flume of the Universidad Politécnica de Valencia (UPV) to investigate the reflection behavior of several perforated-wall breakwater caisson models. The UPV wave flume is 30.0 meters long, 1.2 meters wide and 1.2 meters deep; it is equipped with a piston wave generator with AWACS active wave absorption system.

Fig. 3 and Fig. 4 show the cross section and front view of the anti-reflective caisson model. First, a series of physical 1/35 scale experiments were carried out to compare wave reflection performance of a typical Mediterranean conventional circular cell caisson (M0: 36.9m x $15.7 \mathrm{~m}$ $\mathrm{x} 17.0 \mathrm{~m})$ with three low-reflective caissons (M1, M2 and M3). M1 $\left(\mathrm{d}_{\mathrm{c}}[\mathrm{m}]=1.0\right)$ and $\mathrm{M} 2$ $\left(\left[\mathrm{d}_{\mathrm{c}}[\mathrm{m}]=2.0\right)\right.$ are Jarlan-type caisson models. M3 (Fig. 5) is a low-reflectivity multi-cell circuit caisson (window dimensions $[\mathrm{m}]=2.6 \times 2.0$ ).

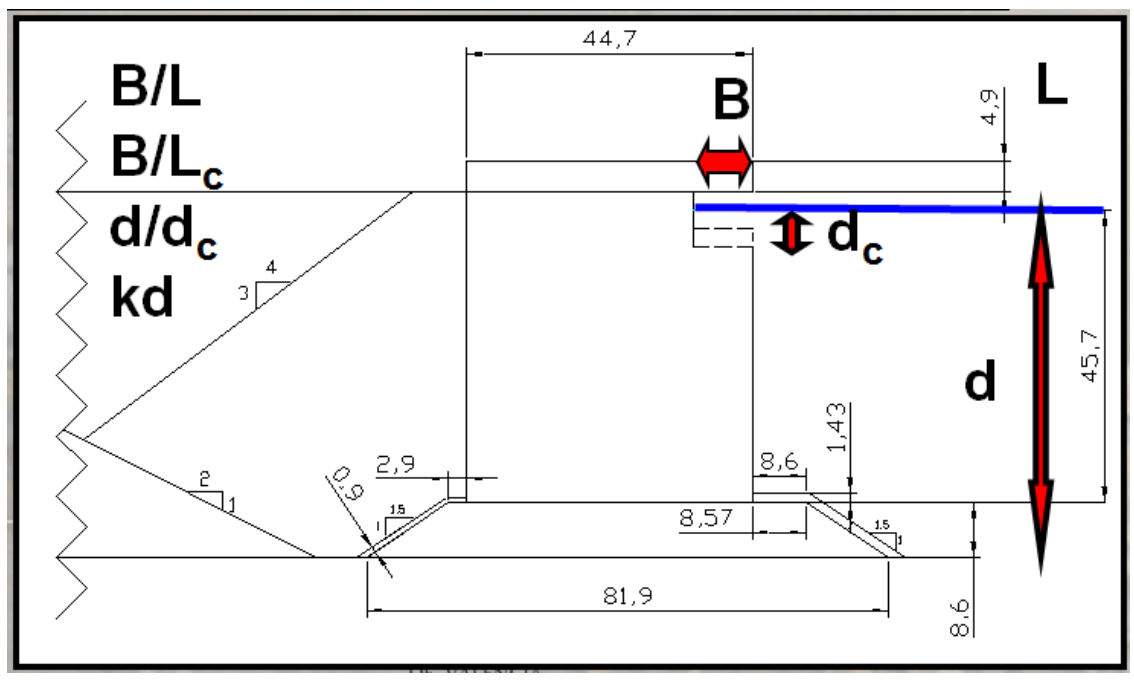

Figure 3.- Cross section of anti-reflective caissons tested in wave flume (dimensions in $\mathrm{cm}$.) 


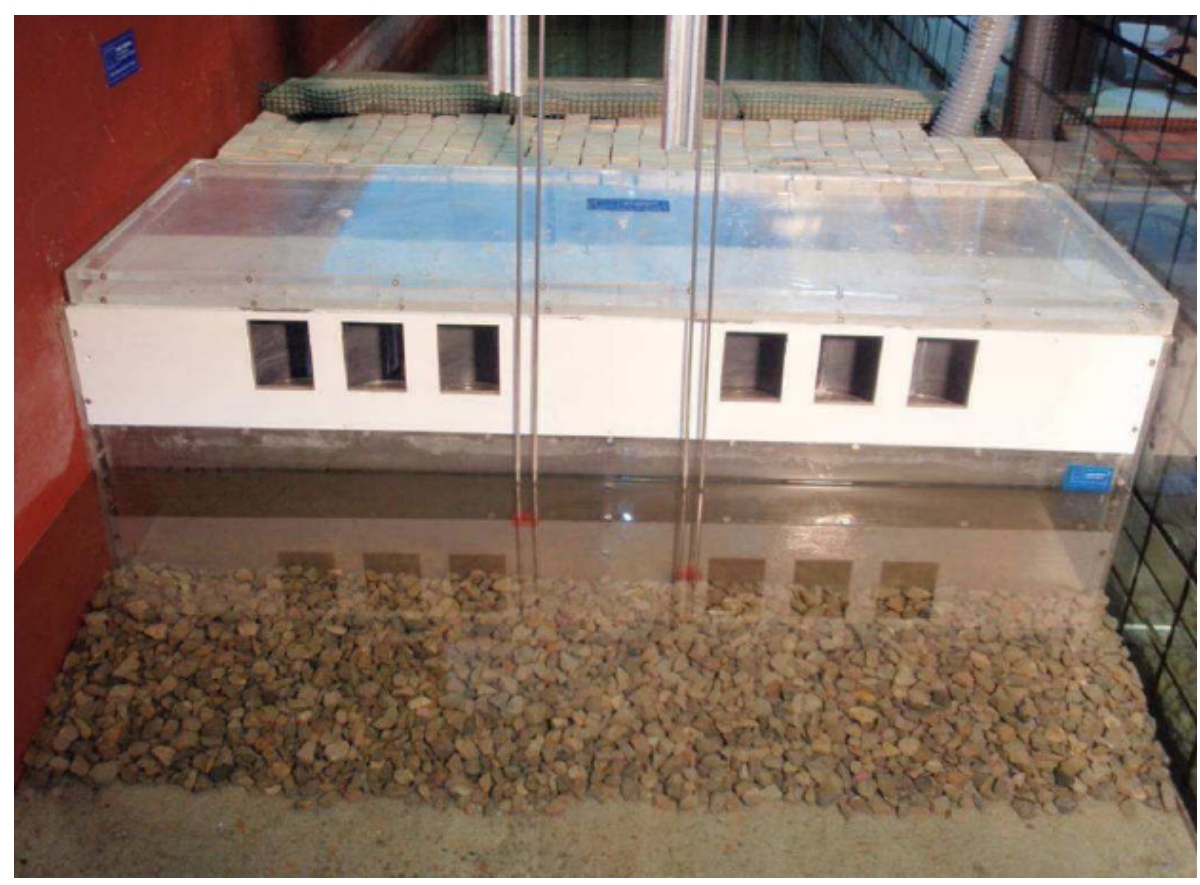

Figure 4.- Front view of new low-reflectivity caisson model (scale 1:35)

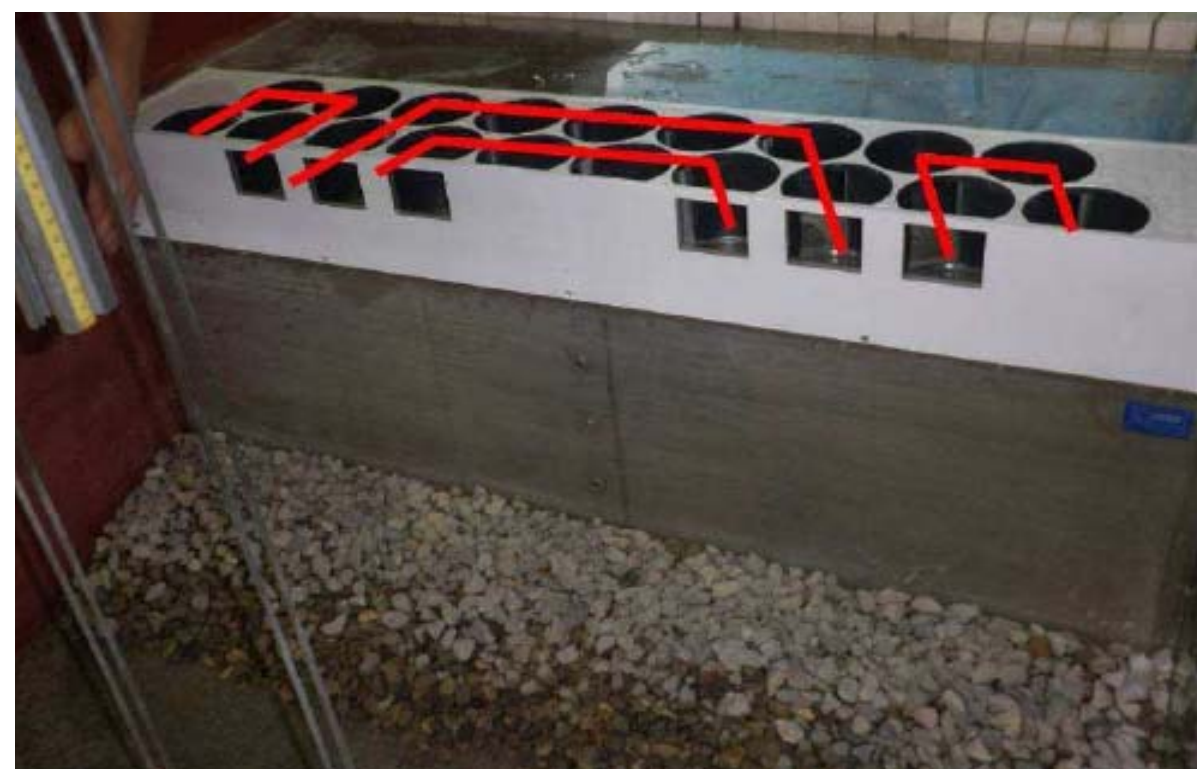

Figure 5.- Low-reflectivity multi-cell circuit caisson model M3

Tests with regular and irregular waves were carried out with wave trains at very-highfrequency $(\mathrm{f}[\mathrm{Hz}]>0.2)$, high-frequency $(0.2<\mathrm{f}[\mathrm{Hz}]<0.1)$ and low-frequency $(\mathrm{f}[\mathrm{Hz}]<0.1)$, considering an incident wave height $\mathrm{H}[\mathrm{m}]=1.0$ at prototype scale. The incident and reflected waves were analyzed using the time-domain LASA method (Medina 2001), which is able to separate nonlinear incident and reflected waves in non-stationary conditions.

\section{ANALYSIS OF RESULTS}

The neural network methodology with pruned neural networks (NN) used by Medina et al. (2002) was used to model the nonlinear relationship observed between CR and the structural and wave conditions. Pruned NN models by Evolutionary Strategies can be considered multiparametric nonlinear regression methods which are able to capture hidden complex nonlinear relationships between input and output variables. This methodology has been used to select 
significant variables and to analyze and compare results. Eighty percent of the data were randomly selected for training and $20 \%$ for testing. The NN model validation criterion depended on the similitude between the mean squared error (MSE) for training and testing data. It has been found that both $\mathrm{B} / \mathrm{L}_{01}$ and $\mathrm{B} / \mathrm{L}_{01 \mathrm{c}}$ described the observed results satisfactorily, where $B$ is the width of anti-reflective zone, $L_{01}$ is the wave length in the basin and $\mathrm{L}_{01 \mathrm{c}}$ is the wave length inside the caisson cell. Fig. 6 compares the reflected energy percentage (\%ER) observed and estimated by the NN models and Figure 7 shows $\% \mathrm{ER}$ as function of $\mathrm{B} / \mathrm{L}$, for M1, M2 and M3 low-reflectivity caissons.

The reflected energy percentage $\left(\% \mathrm{ER}=\mathrm{CR}^{2}\right)$ is used to compare reflection performance from models M1, M2 and M3. The experimental data range were $0.06<\mathrm{d}_{\mathrm{d}} / \mathrm{d}<0.15,0.13<\mathrm{kd}<8.85$ y $0.03<\mathrm{B} / \mathrm{L}_{01 \mathrm{c}}<0.71$, in which $\mathrm{d}$ and $\mathrm{d}_{\mathrm{c}}$ are the water depths at wave basin and chamber respectively and $k=2 \pi / \mathrm{L}_{01}$ is the wave number corresponding to wave length at wave basin, $\mathrm{B}[\mathrm{m}]=7.0$.

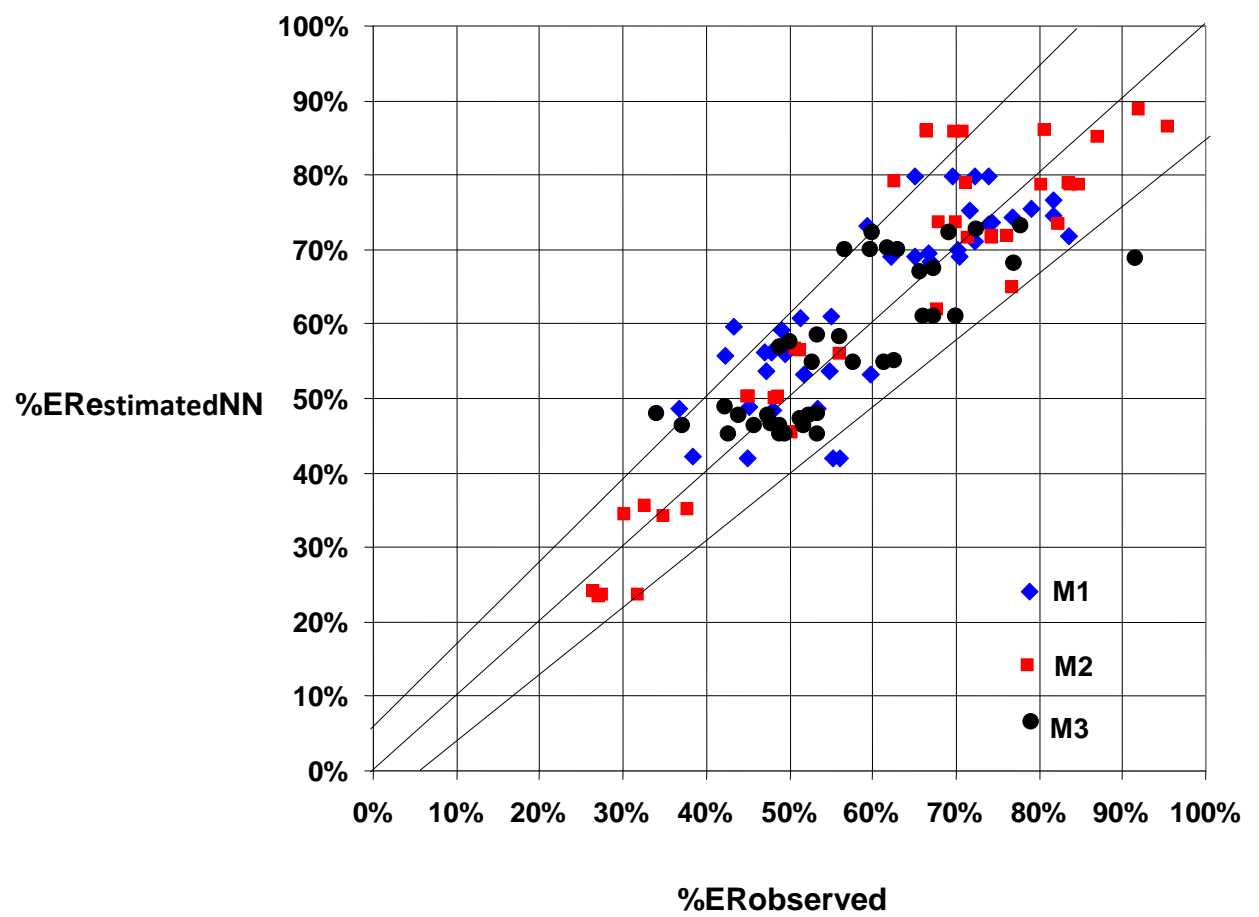

Figure 6.- \%ER observed versus \%ER estimated by NN model

As a result, it is found that the low-reflective caissons with deeper cells (M2) are more effective than caissons with shallow cells (M1) for high-frequency waves, but they are less effective for very-high-frequency waves. The multi-cell circuits model (M3) is more effective for low-frequency waves (Fig. 6). 


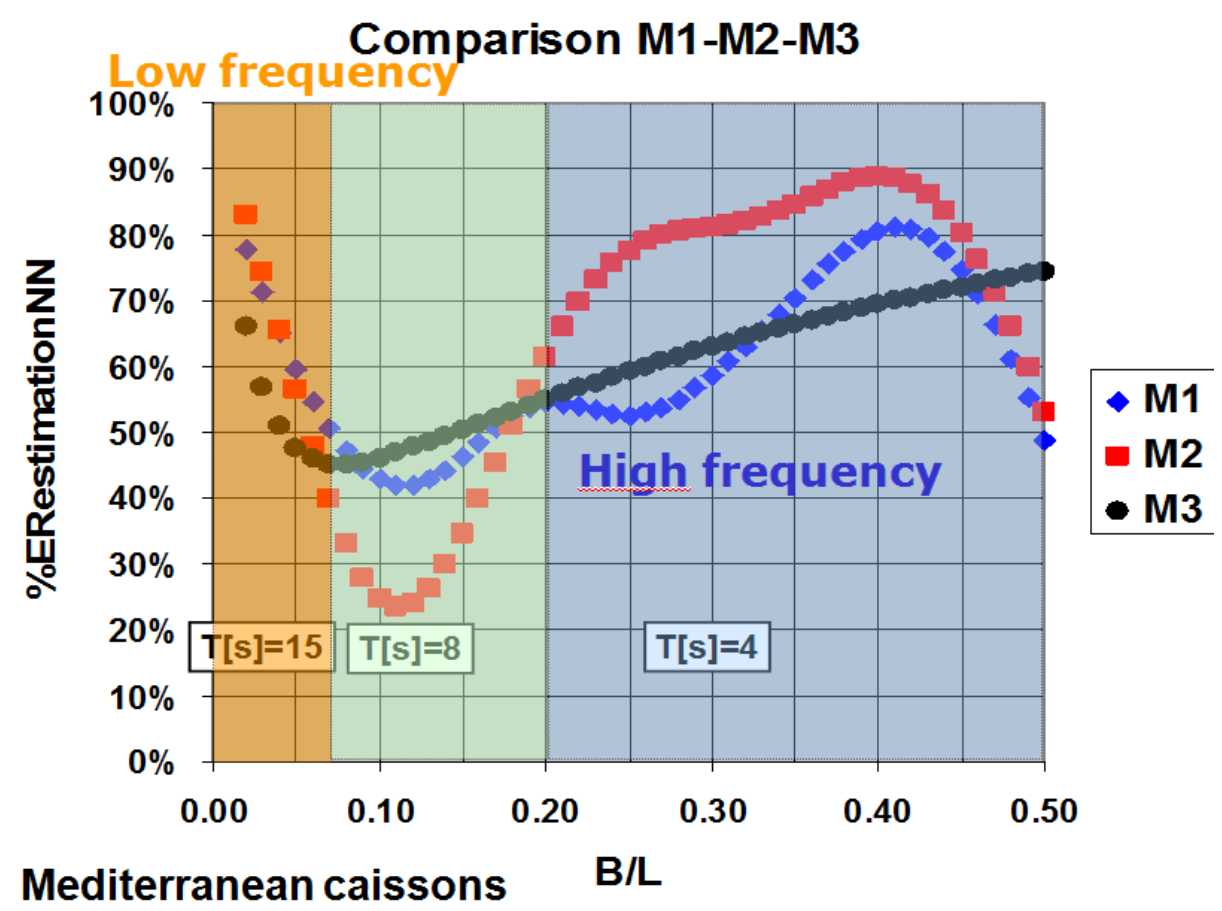

Figure 7.- \%ER(B/L) for caissons M1, M2 and M3

\section{CONSTRUCTION FEASIBILITY}

The construction feasibility of window-type openings in caisson cells was tested at prototype scale with satisfactory results using the CYES caisson production facility. Caissons were manufactured, floated-out, towed, sunk and placed in the Northern Breakwater Extension of the Port of Valencia. Figure 8 shows the prototype scale "stadium caisson" photographs where outer windows are pointed out. In addition to construction effectiveness, the methodology used provided robust structural performance and durability with minor increase in execution periods and costs.
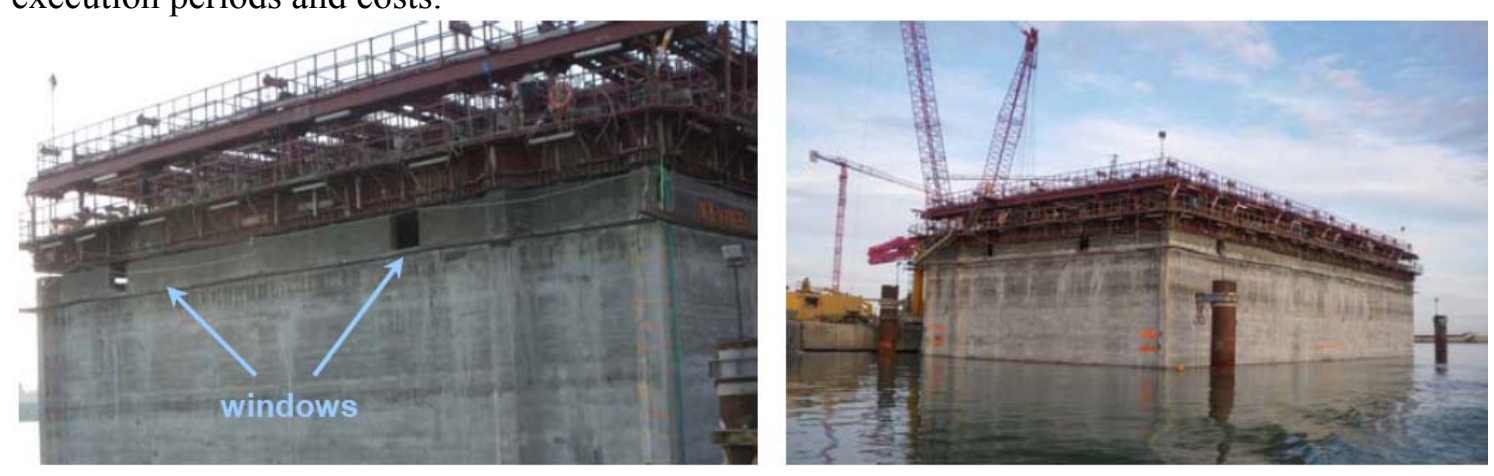

Figure 8.- CYES floating dock facility

Construction solutions were tested at prototype scale, such as special inner formwork and outer windows, towing, sinking and placement. Figure 9 shows the sealed pieces used during the building of the windows to avoid concrete leakage during the pouring procedure. 


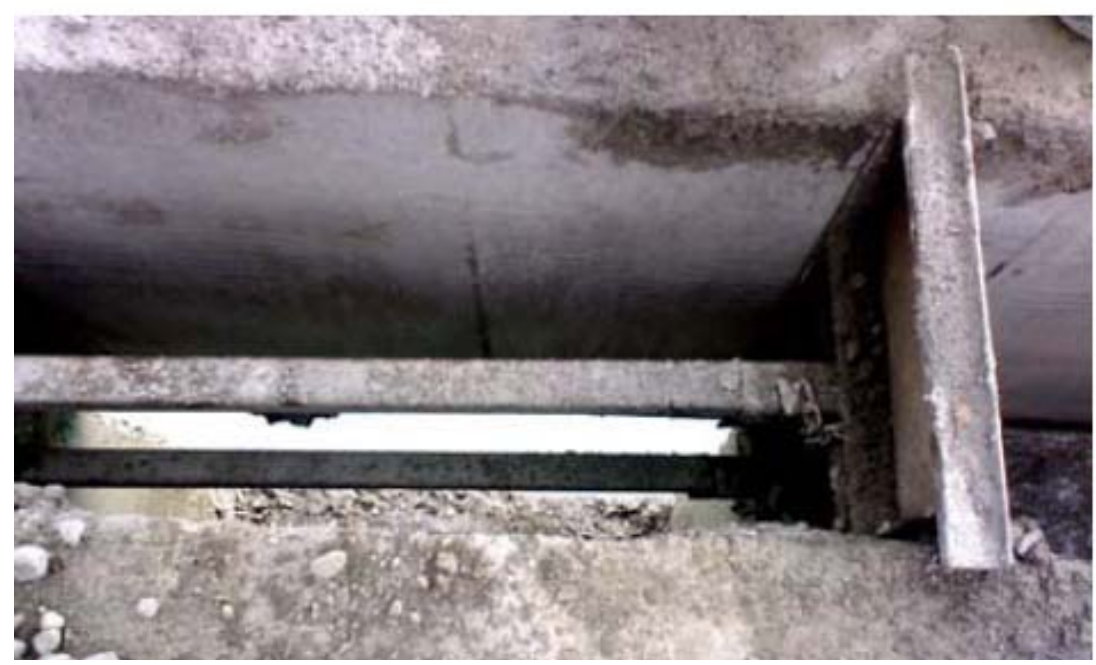

Figure 9.- Sealed pieces and cover protection for towing in manufacturing caisson process

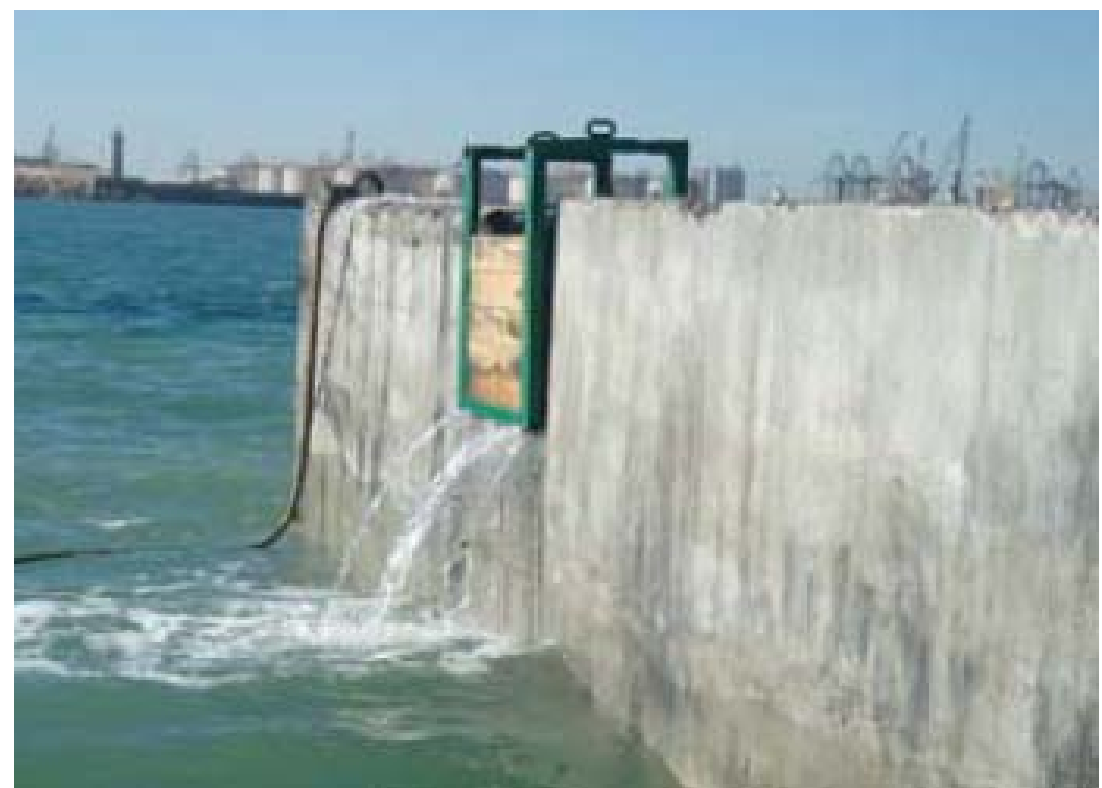

Figure 10.- Cap used for closing external windows in caisson.

Figure 10 shows the cap used for closing external windows. Figure 11 shows part of the cover protection piece fixed in the towing process, which can be used as a support surface to construct the superstructure. Most construction procedures are similar to those of conventional caissons. 


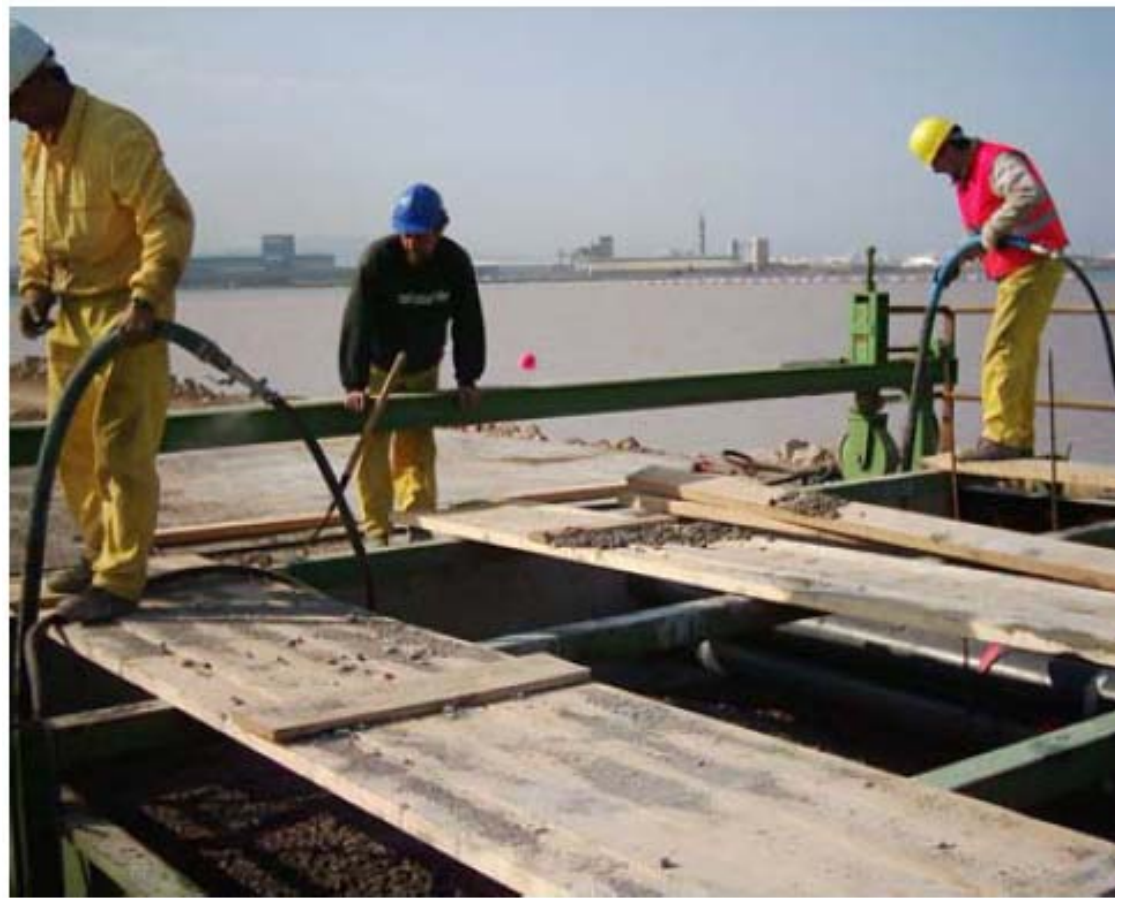

Figure 11.- Superstructure execution over quay wall caisson

Finally, the new multi-cell low-reflectivity caisson was dimensioned using an FEM numerical model to provide the proper steel reinforcement to assure caisson resistance during construction and service. The optimum reinforcement was previously determined and the increase in steel consumption was not relevant compared to a conventional fully-reflective caisson. Figure 12 shows the reinforcement graph corresponding to the multi-cell circuit caisson (M3 model).

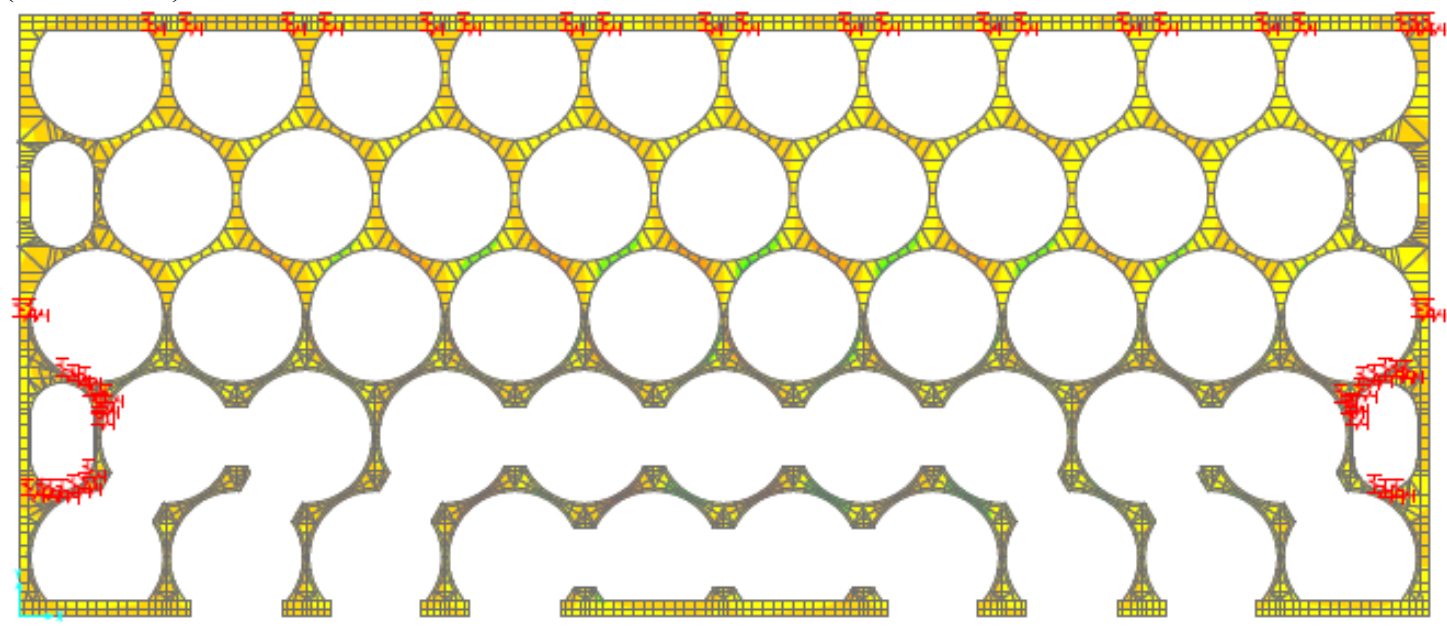

Figure 12.- Steel reinforcement and stress map of a multi-cell circuit caisson

\section{CONCLUSIONS}

A new concept of multi-cell circuit scheme is considered to be especially effective in reducing low-frequency wave reflection. The basic idea of the multi-cell circuit scheme is to connect caisson cells in two directions to create circuits of sufficient length and also to optimize the given response to low-frequency incident waves. Instead of having a caisson's performance conditioned by the anti-reflective zone width, fixed in most cases, caissons can be designed to be especially efficient for a given spectral bandwidth including very-low-frequency waves. Hydrodynamic, dimensioning and construction criteria were established for the wave frequencies ranges: very high $(\mathrm{f}[\mathrm{Hz}]>0.2)$, high $(0.2<\mathrm{f}[\mathrm{Hz}]<0.1)$ and low $(\mathrm{f}[\mathrm{Hz}]<0.1)$, with an incident wave height $\mathrm{H}[\mathrm{m}]=1.0$. 
A new low-reflective vertical caisson using the multi-cell circuit concept was designed and tested in the 2D wave flume in the Laboratory of Ports and Coasts at the UPV. The result of the small scale physical laboratory tests provided a comparison between different typologies of the Jarlan-type breakwater and the new low-reflective caisson. As a result, it was found that the low-reflective caissons with deeper cells are more effective than caissons with shallow cells for high-frequency waves, but they are less effective for very-high-frequency waves; multi-cell circuits are also more effective for low-frequency-waves.

Construction design was considered in terms of manufacturing systems on floating docks, sliding forms adjustment, reinforcement, flotation, navigability, anchor procedure and superstructure. Both equipment and manufacturing procedures were adapted to produce economically-competitive low-reflectivity caissons were tested in the prototype.

It can be concluded that the new low-reflectivity prefabricated floating caisson has achieved a balance in terms of reflectivity reduction, cost, manufacturing time and feasibility in comparison with Jarlan-type breakwaters.

\section{ACKNOWLEDGMENTS}

The authors wish to acknowledge Spanish Ministerio de Fomento for the partial funding of the CADIMA research project. The authors thank the Valencia Port Authority for logistic support for the constructability tests at the new breakwater. The authors also thank Guillermo Zarranz, Enrique Ripoll and César Moreno for assisting with the laboratory tests and Lia Wallon for revising the manuscript.

\section{REFERENCES}

Bergmannn, H., and H. Omeraci. 2000. Wave loads on perforated caisson breakwaters, Proceedings of the $27^{\text {th }}$ International Conference on Coastal Engineering, ASCE, 1622-1635.

Dhinakaran, G., V. Sundar, R. Sundaravadivelu, and K.U. Graw. 2002. Dynamic pressures and forces exerted on impermeable and seaside perforated semicircular breakwaters due to regular waves, Ocean Engineering, 29, 1981-2004.

Esteban, F., and R. Llamas. 2007. Estructura de baja reflexión. Patente de invención n 2262405. Oficina española de patentes y marcas (in Spanish).

Franco, L. 1994. Vertical breakwaters: the Italian experience, Coastal Engineering, 22, 31-55.

Fugazza M., and L. Natale. 1992. Hydraulic performance of perforated breakwater, Journal of Waterway, Port, Coastal, and Ocean Engineering, ASCE, 118, 1-14.

Garrido, J.M., and J.R. Medina. 2006. Study of Reflection of Perforated Vertical Breakwaters, Proceedings of the $30^{\text {th }}$ International Conference on Coastal Engineering, ASCE, 2165-2177.

Garrido, J.M., and J.R. Medina. 2007. Modelo Neuronal para Estimar la Reflexión del Oleaje en Diques Verticales Antirreflejantes. Libro de Ponencias de las IX Jornadas Españolas de Costas y Puertos, AZTI-Tecnalia, 486-495 (in Spanish).

Hagiwara K. 1984. Analysis of upright structure for wave dissipation using integral equation, Proceedings of the $19^{\text {th }}$ International Conference on Coastal Engineering, ASCE, 2810-2826.

Jarlan, G.E. 1961. A perforated vertical breakwater, The Dock and Harbour Authority, 41(486), 394-398.

Jarlan, G.E. 1965. The application of acoustic theory to the reflective properties of coastal engineering structures, Quarterly Bulletin, National Research Council Canada, 23-64.

Jianyi, W. 1992. Experimental study of perforated caisson breakwater, China Ocean Engineering, 6, 6578.

Kakuno S., G. Tsujimoto, and Y. Shiozaki. 2003. A design method for double slit-wall breakwaters, Proceedings of the International Conference on Coastal Structures 2003, ASCE, 295-304.

Kondo H. 1979. Analysis of breakwaters having two porous walls, Proceedings of the International Conference on Coastal Structures 1979, 962-977.

Marks, W., and G.E. Jarlan. 1968. Experimental studies on a fixed perforated breakwater, Proceedings of the $11^{\text {th }}$ International Conference on Coastal Engineering, ASCE, 1121-1140.

Martinez, S., J. Manuel, D. Yagüe, J.M. Garrido, D. Ponce de León, A. Berruguete, J.A. GonzálezEscrivá, and J.R. Medina. 2010. Designing a new low-reflectivity quay wall caisson. Proceedings of the PIANC MMX Congress Liverpool, paper N. 146. 
Medina, J.R. 2001. Estimation of incident and reflected waves using simulated annealing, Journal of Waterway, Port, Coastal and Ocean Engineering, ASCE, 127, 213-221.

Medina, J.R., González-Escrivá, J.A., Garrido, J.M. and De Rouck, J. 2002. “Overtopping analysis using neural networks". Proc. ICCE 2002, ASCE, pp. 2165-2177.

Medina, J.R, J.A. González-Escrivá, L. Fort, S. Martínez, C. Dolores, D. Ponce de León, J. Manuel, D. Yagüe, J.M. Garrido, and A. Berruguete. 2009. Estructura Marítima Vertical con Cámaras de Unidades Múltiples para la Atenuación de la Reflexión de Oleaje. Patent ES200931049 presented at Spanish Patent Office (in Spanish).

Suh, K.D., and W.S. Park. 1995. Wave reflection from perforated-wall caisson breakwaters, Coastal Engineering, 26, 177-193.

Tabet-Aoul, E., and E. Lambert. 2003. Tentative new formula for maximum horizontal wave forces acting on perforated breakwater caisson, Journal of Waterway, Port, Coastal, and Ocean Engineering, 129, 34-40.

Takahashi S., and S. Hosoyamada. 1994. Hydrodynamic characteristics of sloping-top caissons, Proceedings of International Conference on Hydro-technical Engineering for Port and Harbour Construction, PHRI, 1994.

Takahashi, S., 1996. Design of vertical breakwater, Reference Document, No. 34, Port and Harbour Research Institute.

Takahashi, S., Y. Kotake, R. Fujiwara, and M. Isobe. 2002. Performance evaluation of perforated-wall caissons by VOF numerical simulations, Proceedings of the $28^{\text {th }}$ International Conference on Coastal Engineering, ASCE, 1365-1376. 